\title{
Two new threatened species of Rinorea (Violaceae), forest trees from East and South Regions, Cameroon
}

\author{
Gaston Achoundong1 \& Martin Cheek ${ }^{2,3}$ \\ ${ }^{1}$ IRAD-Cameroon National Herbarium, BP 1601, Yaoundé, Cameroon, e-mail \\ gachoundong@yahoo.fr, \\ ${ }^{2}$ Herbarium, Royal Botanic Gardens, Kew, Richmond, Surrey TW9 3AE, United Kingdom. \\ ${ }^{3}$ Corresponding author. Email m.cheek@kew.org
}

Summary. Two tree species are described as new to science: Rinorea spongiocarpa Achound. sp. nov (placed in Rinorea [unranked] Brachypetalae) and Rinorea dimakoensis Achound.sp. nov.( placed in Rinorea [unranked] Ilicifolieae). Both species are endemic to Cameroon, occurring south of the Sanaga river, the first from South and East Regions, occurring in evergreen forest from Ebolowa to Dja, while the second occurs in the northern part of East Region in semi-deciduous forest towards the interface with woodland habitats in the Dimako-Bertoua area. The two species are illustrated, and their affinities and conservation status according to the 2012 IUCN categories and criteria are discussed. Both species are threatened with extinction due to habitat destruction, the first is assessed as Vulnerable, the second Endangered.

Key Words. Butterflies, conservation, Cymothoe; hydro-electric projects; Lom-Pangar; semideciduous forest.

\section{Introduction}

In the course of revising the species of Violaceae of Africa, mainly in preparation for the account of the Violaceae for the "Flore du Cameroun", the first author has, with collaborators, published 17 new species to science for this group (Achoundong \& Onana 1998; Achound ong \& Bos 1999; Achoundong \& Bos 2001; Achoundong 2003; Achoundong \& Cheek 2003; Achoundong \& Cheek 2005; Achound ong \& Bakker 2006 ; Achoundong et al. 2021). The new species published here have previously been referred to under provisional names (Achound ong 1996; Achoundong 1997; Amiet \& Achoundong 1996; Achoundong 2000; Bakker et al. 2006). In this paper,these two provisional species names are formally published to validate these names.

The most recent studies of the phylogeny and classification of African Rinorea Aubl. are set out by Wahlert (2010), Wahlert \& Ballard (2012) and van Velzen et al. (2015). However, the classification of Brandt (1914) has still not been formally replaced.

The genus Rinorea is pantropical, with 212 species currently accepted by Plants of the World Online (POWO, continuously updated, accessed Oct. 2021). Africa is the most speciesdiverse continent for Rinorea with 110 - 150 species (van Velzen et al. 2015). Rinorea species are mainly forest understorey shrubs or small trees. Morphologically, in continental Africa, they are characterized by having alternate, simple leaves, often with petioles of different lengths on the same stem and a usually long, curving apical bud (in the Neotropics and Madagascar, some species e.g. Rinorea sect. Pubiflora Wahlert \& H. E. Ballard have 
opposite leaves). The flowers are often green, dull yellow, or shades of white and are zygomorphic. There are three sets of petals in Rinorea: an anterior petal (also known as the lower or ventral petal), two lateral petals and two posterior petals. These are likely homologous to the three sets of petals in other strongly zygomorphic genera of Violaceae, such as Viola L.(Wahlert 2010).

The anterior petal is larger than the other petals, and often modified, with taxonomically important, often diagnostic characters. The androecium has a staminal tube which is also zygomorphic: the anterior (lower or ventral) side is longer and entire, while on the dorsal side of many of the African species, the staminal tube is generally shorter and incised with a Vshaped cleft. The fruits are typical of the family: hard and dry (except in a few species where it is spongy, see below), tricoccal, septicidal capsules with parietal placentation.

Rinorea are ecologically important and diverse in African forests, often with several sympatric species in one forest. For example, ten species were recorded in a few square kilometers of the Mefou Proposed National Park near Yaoundé (Achoundong in Cheek et al. 2011). Many species are range-restricted, found in such small areas that they are at risk of extinction from forest clearance. Rinorea dewitii Achound., $R$. fausteana Achound., $R$. simoneae Achound. and $R$. thomasii Achound. are all assessed as threatened in the Red Data Book of the Flowering Plants of Cameroon (Onana \& Cheek 2011) and all but the first can be found on the IUCN Red List (iucnredlist.org) e.g., Rinorea thomasii (Darbyshire \& Cheek 2004a; Cheek 2017; Darbyshire \& Cheek 2004b). In neighbouring Gabon, the recently published Rinorea calcicola Velzen \& Wieringa is also range-restricted and of conservation concern (van Velzen \& Wieringa 2014). Cameroon has the highest species-diversity for the genus in tropical Africa with 53 species listed (Onana 2011), followed by Gabon, with 46 species (Sosef et al. 2006). However, the superficial similarity between species has made identification difficult for taxonomists, e.g., 194 specimens of Rinorea are listed as unidentified to species for Gabon in Sosef et al. (2006).

African Rinorea species are of great interest to entomologists, being important larval food plants of the butterfly genus Cymothoe (the gliders). Twenty-eight species of Cymothoe are known to feed on Rinorea, of which 18 are strictly monophagous, six are oligophagous and three feed on up to six species of Rinorea (Amiet 1997; Amiet 2000; Amiet \& Achoundong, 1996).

\section{Materials \& Methods}

Fieldwork by the first author was mainly carried out in Cameroon from1987 - 1996 in connection with his doctoral studies of Rinorea (Achoundong 1997). All specimens cited have been seen. Herbarium citations follow Index Herbariorum (Thiers et al. continuously updated). Specimens were studied online, on loan from or at BR, K, P, WAG and YA principally by the first author. We also searched JSTOR Global Plants (https://plants.jstor.org/ accessed April 2021) for additional materials. Taxonomic authorities follow the International Plant Names Index (IPNI 2021), and nomenclature follows Turland et al. (2018). The conservation assessment was made using Bachman et al. (2011) following the categories and criteria of IUCN (2012). Herbarium material was examined with a Leica Wild M8 dissecting binocular microscope fitted with an eyepiece graticule. Measurements were made from rehydrated or spirit preserved material. The terms and format of the description follow the conventions of Achoundong \& Cheek (2005) and Achoundong et al. (2021). Post-facto georeferences for specimens without coord inates were obtained from Google Earth. (https://www.google.com/intl/en_uk/earth/versions/ ). 


\section{Results: Taxonomy}

Rinorea spongiocarpa Achound.sp. nov., the first of the two species described below is placed in Rinorea [unranked] Brachypetalae because it is closely similar to $R$. gabunensis and R. leiophylla which are placed in this group on molecular grounds (Wahlert and Ballard 2012; van Welzen et al. 2015) and because it fits the description of this group: alternate leaves, six ovules per ovary, cymose inflorescence, anthers sessile on the border of the staminal tube.

Rinorea dimakoensis Achound. sp. nov. the second species described, is placed in Rinorea [unranked] Ilicifolieae on molecular grounds (Wahlert and Ballard 2012; van Welzen et al. 2015) and because it fits the description of the group: alternate leaves, six ovules per ovary ; cymose inflorescences, sepals clearly ribbed fanwise; staminal tube sinuate between insertion of anthers, tube without a free margin or a lobed margin subtending anthers. Further data are given on Ilicifoliae in Wahlert et al. (2020).

1. Rinorea spongiocarpa Achound. sp nov. Type. Cameroon, South Region, Ebolowa, "Hill facing village of N'Kolandom hill, in primary forest on slope, Alt. c.700 m, 2.48N, 11.10E”, fl. 20 Feb.1975, J.J. F.E. de Wilde 7985 (holotype WAG; isotypes BR, K000593339, P, YA). (Fig. 1).

Rinorea spongiocarpa ined. Achound ong (1996: 536 - 544; 1997: 193 - 198); Amiet \& Achoundong (1996: 465); Onana (2011: 151).

Tree or shrub $2-6(-12) \mathrm{m}$ high; stems glabrous. Leaf-blades leathery to thickly papery, glossy, dark green above, pale yellow-green beneath, elliptic, ovate to narrowly oblong, $14-30$ x $11-6$ $\mathrm{cm}$, apex acuminate, base cuneate to attenuate, lateral nerves $9-12$, on each side of the midrib, tertiary nerves subscalariform, leaf margin crenate, glabrous; petiole $5-7 \mathrm{~cm}$ long. Inflorescence a terminal panicle up to $7 \mathrm{~cm}$ long, lateral ramifications constituted by few-flowered cymes of 5 -7 flowers each. Bracts triangular, $1.5 \times 2 \mathrm{~mm}$, median nerve raised, conspicuous. Flowers yellow or yellow-white, zygomorphic, $4-5(-6) \times 3-4(-5) \mathrm{mm}$. Sepals purple, unequal, triangular to elliptic $2 \times 3 \mathrm{~mm}$, apex rounded. Petals yellow, unequal, anterior (lower) petal oblong $6 \times 2 \mathrm{~mm}$, spreading, not or barely revolute at maturity, lateral and posterior petals smaller, $3-4 \mathrm{~mm}$ long, distal half strongly revolute. Androecium zygomorphic, $3.5-5 \mathrm{~mm}$ long, staminal tube $1-2.5 \mathrm{~mm}$ long, tube margin not free, anthers sessile on the tube border, thecae $2 \mathrm{~mm}$ long, outer surface puberulent, connective appendage $2 \mathrm{~mm}$ long, red, decurrent deeply on the anther thecae, thecae appendage entire, not bifid. Gynoecium up to $5.3 \mathrm{~mm}$ long. Ovary subglobose, $1.5 \times 1 \mathrm{~mm}$, glabrous, style straight, enlarged at the base, $3.5 \mathrm{~mm}$ long. Fruit ovoid, 30 x $20 \mathrm{~mm}$ surface smooth, lacking ribs, fruit wall c. $3 \mathrm{~mm}$ thick, spongy, six-seeded. Seeds white, tetrahedric, $9-10(-11)$ x $9-10 \times 5(-6) \mathrm{mm}$, drying pale brown, glossy.

RECOGNITION. Similar to $R$. parviflora Chipp in the fruits having a thick spongy mesocarp (in almost all other members of the genus the mesocarp is slender and hard), differing in that the abaxial surface of the leaf-blade lacks glands and that the inflorescence branches are many-flowered (vs glandular and 1 -2-flowered respectively).

DISTRIBUTION. Cameroon. The species is restricted to the area of the Dja Forest, East Region, extending westwards to Ngovayang and Ebolowa in Littoral Region.

SPECIMENS STUDIED. CAMEROON. East Region, Alat Makay, Dja National Park, fl.23 Feb.1987, Achoundong 1411 (P, YA); Timbe II, near Abong-Mbang, fl. 20 Jan.1990, Achoundong 1562 (P, YA); Dja National Park., fl. 25 Apr.1993, Lejoly \& Sonké 154 (BR, YA); Dja National Park, Mekas, fl. 10 Jan.1995, Sonké 1385 (BR, YA); Mekas, fr. 26 May 


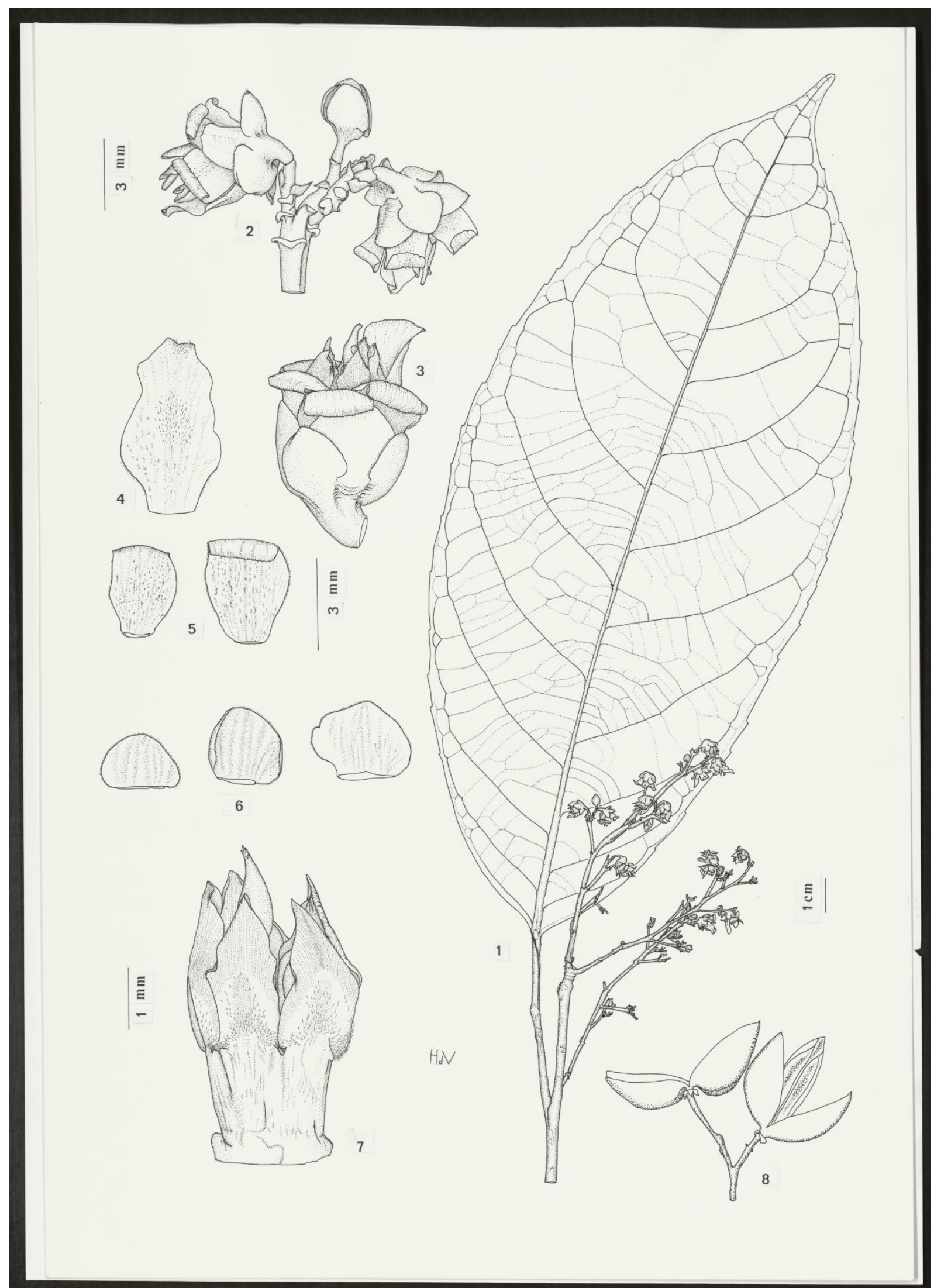

Fig. 1. Rinorea spongiocarpa. A habit, flowering stem; B portion of inflorescence with two open flowers and one flower in bud; $\mathbf{C}$ flower, note the spreading anterior petal; $\mathbf{D}$ anterior petals; E lateral and posterior petals; F sepals; $\mathbf{G}$ androecium, side view; $\mathbf{H}$ fruit, mature. All drawn from J.J. F.E. de Wilde 7798 (holotype, WAG) by J.M. (HANS) DE VRIES 
1995, fr, Sonké 1548 (BR, YA); South Region. Ebolowa, Hill facing village of N'Kolandom hill, in primary forest on slope, fl. 20 Feb. 1975, J.J. F.E. de Wilde 7985 (holotype WAG; isotypes BR, K000593339, P, YA); Nkoladom village, south of Ebolowa, fr. 10 Sept. 1989, Achoundong 1495, (K000593338, WAG, YA); ibid., fl. fr. Sept. 1992, Achoundong 1951 (YA); ibid. Achoundong 1952 (YA); ibid. Achoundong 1953 (YA); Bongolo I, $30 \mathrm{~km}$ on Ebolowa-Lolod orf road, fl., 14 Sept. 1989, Achoundong 1501, (K, YA); ibid., fl., fr., 14 Sept. 1989, Achoundong 1501 (K000593337, P, YA); Avobengon village, $24 \mathrm{~km}$ south of Djoum, 1255’E, 2 40’E, fl., 22 Dec. 1990, Achoundong 1598 (YA); ibid. fl., 22 Dec.1990, Achoundong 1632 (YA); ibid. fl. 22 Dec.1990, Achoundong 1700 (P, YA); ibid., fl. 10 April 1991, Achoundong 1760 (K000593336, WAG, YA); ibid. imm.fr. Achoundong 1802 (K000593335, YA); Medjap, near Djoum, st. 20 May 1990, Achoundong 1681 (P, YA); Mill Hill, Lolodorf, Sept. 1992, Achoundong 1974 (YA); Bibondi near Ngovayang, north West of Lolodorf, fl., 4 March 1993, Achoundong 2017 (YA); ibid. Achoundong 2024 (YA); Mezese, fr. 24 May1993, Achoundong 2066, (YA); Mezese, fr. 16 Sept. 2004, Achoundong 2335 (YA, WAG); Ebienemeyong, fl., Jan.1993, Achoundong 2338 (YA).

HABITAT. This species is widespread in dense lowland evergreen forest of the Cameroon Congolese forest zone (in the sense of Letouzey 1985). It occurs at an altitudinal range of 400-700 m. It does not occur in the littoral plain and is completely absent from the semideciduous forest of the South Cameroon Plateau.

CONSERVATION STATUS. Rinorea spongiocarpa is only known from parts of Littoral Region and the Dja Forest area of adjoining East Region. On the basis of the specimen records cited above, we calculate the total extent of occurrence of Rinorea spongiocarpa as $25,295 \mathrm{~km}^{2}$. However, within this fairly large area, there are currently only nine scattered locations known and the global area of occupation is calculated as only $44 \mathrm{~km}^{2}$ using the IUCN-preferred cell size of $4 \mathrm{~km}^{2}$. Surveys for plant conservation management in forest areas north, south and west of the range of distribution of this species have resulted in many thousands of specimens being collected and identified, but failed to find any additional specimens of Rinorea spongiocarpa (Cheek 1992 ; Cable \& Cheek 1998; Cheek et al. 2000; Maisels et al. 2000 ; Chapman \& Chapman 2001; Tchoutou 2004; Harvey et al. 2004; Cheek et al. 2004; Cheek et al. 2010; Harvey et al. 2010; Cheek et al. 2011). Although there are still poorly sampled forest locations with intact natural habitat in Cameroon, it is likely that the known range of Rinorea spongiocarpa is close to the actual. Only one location for the species occurs in a designated protected area: the Dja forest. The species appears absent from the largest protected area in South Region, the Campo-Ma'an National Park. Despite being formally unprotected, forest at several of the known locations appears mainly intact (Google Earth imagery viewed 29 Oct. 2021), with forest entirely or largely removed only in two or three locations, apparently due to small-holder agricultural operations near roads. Rinorea spongiocarpa is therefore here assessed, on the basis of the ten or less locations, small known area of occupation and threats described above, as Vulnerable, VU B2ab(iii). Another example of a range-restricted endemic species in the same range and habitat is Kupeantha spathulata (A.P.Davis \& Sonké)Cheek (Cheek et al. 2018a), which is also assessed as Vulnerable (Rokni et al. 2017).

ETYMOLOGY. The name of this species derives from its fruit which has a well-developed, thick, spongy mesocarp, while other most species of the genus have slender, more hardwalled fruits.

NOTES. In herbarium collections, specimens belonging to this species appear similar to those of two other species: Rinorea gabunensis Engl. and Rinorea leiophylla M.Brandt to which Rinorea spongiocarpa has long been confused. The species have separate ranges. Rinorea gabunensis and Rinorea leiophylla occur exclusively in the littoral plain whereas Rinorea spongicarpa is 
restricted to forest inland in the Cameroon "congolese forest" zone. The three species are distinguished as follows:

1. Small shrub of less than $5 \mathrm{~m}$ high; lamina with secondary nerves prominent; partialinflorescences (secondary branches) of the inflorescence up to $12 \mathrm{~mm}$ long; fruit ribbed.... Rinorea gabunensis

1. Small tree up to $12 \mathrm{~m}$ high; lamina second ary nerves not prominent; partialinflorescences (second ary branches) of the inflorescence less than $1.4 \mathrm{~mm}$ long; fruit smooth (not ribbed). .2

2. Leaves glandular on abaxial surface; staminal tube with free margin. Rinorea leiophylla

2. Leaves not glandular on abaxial surface; staminal tube margin not free. Rinorea spongiocarpa

2.Rinorea dimakoensis Achound. sp. nov. Type. Cameroon, East Region, Dimako Bonda river, fl. fr.18 Jan.1960, Letouzey 2663 (holotype P; isotype YA)

Rinorea dimakoensis Achound. ined. Achoundong (1996 : 544); (1997 : 156); Amiet \& Achoundong (1996: 466); Bakker et al. (2006); Onana (2011); van Velzen et al. (2015); Wahlert (2010); Wahlert \& Ballard (2012).

Tree or shrub_up to $12 \mathrm{~m}$ tall; stems glabrous. Leaves thickly coriaceous, dark green above, blades elliptic, ovate to narrowly oblong, $30-10 \times 6-18 \mathrm{~cm}$, apex acuminate, base rounded, obtuse or attenuate, lateral nerves $8-10$ on each side of the mid rib, leaf margin acutely serrate, glabrous; petiole $3-6 \mathrm{~cm}$ long. Inflorescence terminal or subterminal panicle $8-12 \times 2-7 \mathrm{~cm}$, lateral branches with $2-5$-flowered cymes; bracts ovate $1.5-2 \times 1-2 \mathrm{~mm}$, rounded at the summit, median nerve conspicuous. Flower yellow, zygomorphic, 4-5 (-6) x 3-4(-5) mm. Sepals unequal, triangular to elliptic orbicular, $2 \times 3 \mathrm{~mm}$, apex rounded or emarginate. Petals yellow, unequal, oblong, $6-7 \times 2-4.2 \mathrm{~mm}$, lateral and dorsal petals smaller, anterior (lower) petal bigger, straight, not revolute at maturity. Androecium zygomorphic, $3.5-5 \mathrm{~mm}$ long. Staminal tube $0.5 \mathrm{~mm}$ long, tube margin not free, anthers sessile on the rim of the staminal tube; staminal thecae $2 \mathrm{~mm}$ long, connective subelliptic, c. $2 \mathrm{~mm}$ long, apex round ed, thecae base decurrent slightly, thecal appendage entire (not bifid). Gynoecium $3 \mathrm{~mm}$ long. Ovary glabrous, subglobose, $1 \mathrm{~mm}$ long, style $2 \mathrm{~mm}$ long. Fruit ovoid, 3.5 x $3 \mathrm{~cm}$, longitudinally 3 -ribbed, 6seeded. Seeds tetrahedric, 8 x $5 \mathrm{~mm}$.

RECOGNITION. Rinorea dimakoensis Achound. is similar to R. ilicifolia Kuntze, in the shape and size of the leaves which are leathery and robustly toothed at the margin, however in Rinorea dimakoensis the leaves are wider ( $6-18 \mathrm{~cm}$ vs $3-9 \mathrm{~cm}$ ) and the spines are shorter ( $<0.5 \mathrm{~mm}$ long vs $1-2 \mathrm{~mm}$ long), the inflorescences, pedicels, flowers and fruits are longer and/or larger, reaching $8-12 \mathrm{~cm}, 4.5 \mathrm{~mm}, 7 \times 4 \mathrm{~mm}$, and $3.5 \mathrm{~cm}$ long respectively (vs $3-5$ $\mathrm{cm}, 1 \mathrm{~mm}, 3.5-4 \times 3-4 \mathrm{~mm}$, and $1.2-1.6 \mathrm{~cm}$ long and the sepals have only the midrib raised and partly rib-like, not with multiple raised longitudinal ribs. 


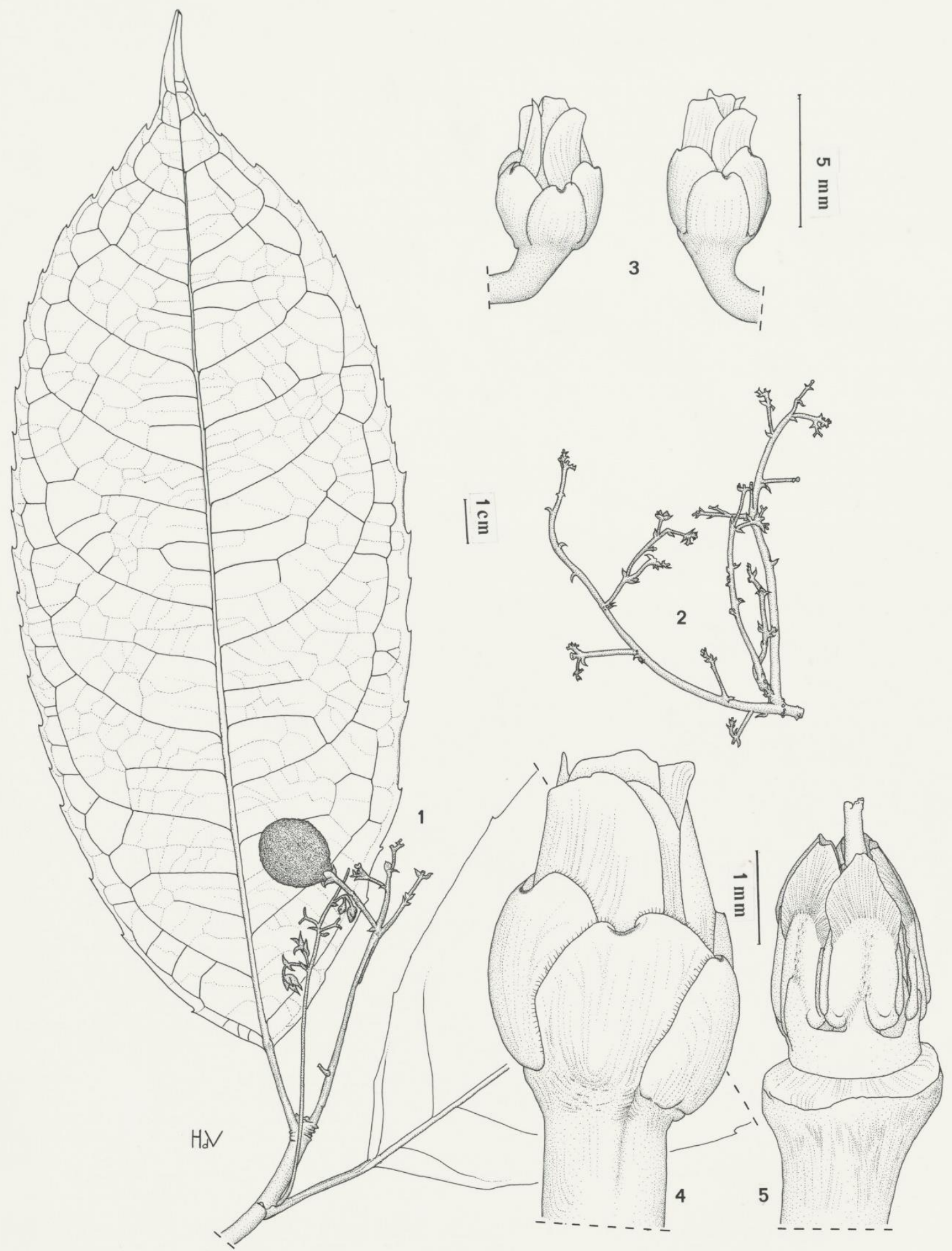

Fig. 2. Rinorea dimakoensis. A habit, fruiting stem; B portion of infructescence axis; $\mathbf{C}$ two flowers, side view; D flower, side view; $\mathbf{E}$ sepals; $\mathbf{F}$ androecium, side view; $\mathbf{G}$ fruit, mature. A, C-D from Achoundong 3033 (WAG, YA), B from Letouzey 2663 (holotype P). Drawn by J.M.(HANS) DE VRIES 
DISTRIBUTION. Cameroon. The species is globally endemic to a narrow area on the South Cameroon Plateau of East Region, extending from Dimako in the south to the Lom-Pangar in the north.

SPECIMENS STUDIED. CAMEROON. East Region. South Dimako, Bonda River, fl.fr.10 Aug.1987, Achoundong 1878 (P, YA); Confluence du Lom et du Pangar, fl. date unknown, Achoundong 3033 (WAG, YA); South of Dimako, Bonda river, fl. fr. 18 Jan. 1960, Letouzey 2663 (holotype P, isotype YA); Ndemb II, $55 \mathrm{~km}$ along Ndemba road, st. 17 Nov. 1955, Nana 343 (P, YA); 60 km on Bertoua Road., Essengue ll path, st. 18 Feb.1956, Nana 489 (YA).

HABITAT. Rinorea dimakoensis is globally restricted to semi-deciduous forest at $680-720 \mathrm{~m}$ alt. The distribution range of this species falls within the transition from forest to grassland in Cameroon, with forest mainly along drainage lines interd igitating with grassland on betterdrained areas. The species is completely absent from semi-deciduous forest in the adjoining Centre Region, e.g in the Yaounde and Bafia areas. It is also completely absent from Cameroon coastal (littoral) evergreen forest, where its relative Rinorea ilicifolia occurs.

CONSERVATION STATUS. Formerly three locations were known for Rinorea dimakoensis. However, the species has been lost at its former northernmost location which has now been inund ated (viewed on Google Earth 29 0ct. 2021) by the reservoir behind the LomPangar hydro-electric dam, which was completed in 2017. It is to be hoped that searching in surviving suitable habitat in the area might discover additional individuals but this is not certain. Forest at the remaining two locations appears to have been shrinking and has been degraded over recent years, probably due to urbanisation, and the demand for fuel in neighbouring Dimako and Bertoua, towns along the transnational highway that links Douala, Yaounde and Bangui, the major artery for the Central African Republic. On the basis of the specimen records cited above, we estimate the total extent of occurrence of Rinorea dimakoensis as $705 \mathrm{~km}^{2}$ (including the Lom-Pangar site) and the global area of occupation is calculated as only $8 \mathrm{~km}^{2}$ using the IUCN-preferred cell size of $4 \mathrm{~km}^{2}$. There are currently only two extant locations known. It is possible that additional locations will be found within the extent of occcurence and that this itself might be extended since this area of Cameroon is less well surveyed than that of the main forest zone (see references cited under Rinorea spongiocarpa). However, while it is possible that additional locations might be found, it may also be that the species is truly as localised, range-restricted and threatened as the data indicates, as are several other species of the genus in Cameroon (see introduction above). We here assess Rinorea dimakoensis on the basis of the data given above, as Endangered, EN $\mathrm{B} 1+\mathrm{B} 2 \mathrm{ab}(\mathrm{iii})$. Another example of a range-restricted endemic species in the same range is Alliphylus bertoua Cheek, also Endangered (Cheek \& Haba 2016).

ETYMOLOGY. The species is named after the Dimako locality in East Region, where the first fertile specimen representing this species was collected in 1960 by Letouzey.

NOTES. Rinorea dimakoensis appears both closely similar and related to R. ilicifolia Engl. From field observations it appears that Rinorea dimakoensis differs in the shape and size of the habit, the structure of the leaf margin, the architecture of the inflorescence and the habitat. This close similarity probably constitutes one of the reasons why this species has not been recognized previously. In fact the first specimen of this species collected by Letouzey was erroneously identified as Rinorea ilicifolia. Since discriminating characters are mainly located in mature flowers, it was not easy for botanists formerly to separate this species. Rinorea dimakoensis is also similar to Rinorea keayii. However, in Rinorea dimakoensis leaves margins are so not spiny as those of this species and the lamina is not glandular beneath. 


\section{Discussion.}

Documented global extinctions of plant species are increasing (Humphreys et al. 2019) and recent estimates suggest that as many as two fifths of the world's plant species are now threatened with extinction (Nic Lughadha et al. 2020). Cameroon has the highest documented number of plant species extinctions of any country in tropical Africa (Humphreys et al. 2019). The endemic Cameroon species Oxygyne triandra Schltr. and Afrothismia pachyantha Schltr. are among those now known to be globally extinct (Cheek \& Williams 1999, Cheek et al. 2018b, Cheek et al. 2019) and two recently two species of Pseudohydrosme (Moxon-Holt \& Cheek 2021; Cheek et al. 2021) have been shown to be extinct in adjoining Gabon. In some cases, species appear to have become extinct even before they are known to science, such as Vepris bali Cheek (Cheek et al. 2018c), also in Cameroon. Even areas known to be of high conservation value have been slated for development, threatening the species they contain with extinction, e.g. the Ebo forest in Cameroon (Lovell 2020).

About 2000 plant species new to science are published each year, with Cameroon contributing more than any other tropical African country in 2019 (Cheek et al. 2020). Only when such species as Rinorea spongiocarpa and $R$. dimakoensis (this paper) are formally known to science are they fully visible and can extinction risk assessments be accepted by IUCN allowing the possibility of measures being taken to protect them (Cheek et al. 2020).

Efforts are now being made to delimit the highest priority areas in Cameroon for plant conservation as Tropical Important Plant Areas (TIPAs) using the revised IPA criteria set out in Darbyshire et al. (2017). This is expected to help avoid the global extinction of additional endemic species such as the Rinorea species published in this paper which it is intended will be included in the future TIPAs.

Acknowledgements. The first author thanks IRAD-National Herbarium of Cameroon (YA) for support in his retirement that has enabled him to continue and finalise his taxonomic research on Violaceae of Cameroon for the Flore Du Cameroun. The Nederlandese Organisatie voor Wetenschappelyk Onderzoek (NOW), Institut de Recherche pour le Developement (IRD) and Royal Botanic Gardens, Kew have supported the cost of visits by the first author to the European herbaria of BR, BM, K, P and WAG. The first author is particularly grateful to Jos van der Maesen, Frans Breteler and Eric Chenin at these institutions. He also thanks colleagues at Wageningen for retrieving and transmitting the excellent figures that illustrate this paper, drawn by J.M. (Hans) de Vries. This paper was completed as part of the Cameroon TIPAs (Tropical Important Plant Areas) project at RBG, Kew, which is supported by players of People's Postcode Lottery. Formal Red Listing of these two tree species, once they are formally published, will be supported by the John S. Cohen Found ation.

\section{References}

Achoundong, G. (1996). Les Rinorea comme indicateurs des grands types forestiers du Cameroun. In: van der Maesen, L.J.G., van der Burgt, X.M. \& Van Medenbach-de Rooy, J.M. (eds) The Biodiversity of African Plants. Kluwer Academic Publishers, Dordrecht, pp. 536544. http://dx.doi.org/10.1007/978-94-009-0285-5_69 
Achoundong, G. (1997). Rinorea du Cameroun, systematique Biologie, Ecologie, Phytogeographie. These Universite de Yaoundé I, Yaoundé.

Achoundong, G. (2000). Les Rinorea et l'étude des refuges forestiers en Afrique. In: Servant, M. \& Servant-Vildary, S. (eds) Dynamique à long terme des écosystèmes forestiers intertropicaux. Mémoire UNESCO, Paris. pp 19-29

Achoundong, G. (2003) Novitates Gabonenses 45. Une nouvelle espèce de Rinorea (Violaceae) du Gabon. Adansonia n.s. 25: 211-215.

Achoundong, G. \& Bakker, F. T. (2006). Deux nouvelles espèces de Rinorea, série Ilicifoliae (Violaceae) du Cameroun. Adansonia, sér. 3, 28 (1): 129 - 136.

Achoundong, G. \& Bos, J.J. (1999). Novitates Gabonenses: 37. Espèces nouvelles de Rinorea (Violaceae) du Gabon. Adansonia 21 (1): 125 - 131

Achoundong, G. \& Bos, J.J. (2001). Deux espèces nouvelles de Rinorea (Violaceae) du Congo et du Gabon. Adansonia 23(1): 155 - 159.

Achoundong, G. \& Cheek, M. (2003). Two new species of Rinorea (Violaceae) from western Cameroon. Kew Bulletin 58: 957 - 964. https://doi.org/10.2307/4111209

Achound ong G. \& Cheek, M. (2005). Two further new species of Rinorea (Violaceae) from Cameroon. Kew Bulletin 60(4): 581 - 586

Achoundong, G. \& Onana, J. (1998). Allexis zygomorpha (Violaceae): a new species from the Littoral Forest of Cameroon. Kew Bulletin 53(4): 1009 - 1010. https://doi.org/10.2307/4118897

Achoundong, G., van der Burgt, X., Cheek, M. (2021). Four new threatened species of Rinorea (Violaceae), treelets from the forests of Cameroon bioRxiv. https://doi.org/10.1101/2021.05.19.444792

Amiet, J.-L. (1997) Spécialisation trophique et premières états chez les Cymothoe: implications taxonomiques (Lepidoptera, Nymphalidae). Bulletin de la Société entomologique de France 102: 15-29.

Amiet, J.-L. (2000) Les premiers états des Cymothoe: Morphologie et intérêt phylogénique (Lepidoptera, Nymphalidae). Bulletin de la Société entomologique de France 106: 349-390

Amiet, J. L. \& Achound ong, G. (1996). Un exemple de speciation trophique chez les Lepidopteres: les Cymotoe camerounaises infeodees au Rinorea (Violacies) (Lepidoptera, Nymphalidae). Bull. Soc. Entom. Fr. 105(5): 449 - 466.

Bachman, S., Moat, J., Hill, A., de la Torre, J., Scott, B. (2011). Supporting Red List threat assessments with GeoCAT: geospatial conservation assessment tool. ZooKeys. 150: 117 126. https://doi.org/10.3897/zookeys.150.2109 
Bakker, F. T., van Gemerden, B. S. \& Achoundong, G. (2006). Molecular systematics of African Rinorea Aublet. (Violaceae). Pp. 33 - 44 in S. A. Ghazanfar and H. J. Beentje (eds.) Taxonomy and ecology of African plants, their conservation and sustainable use. Royal Botanic Gardens, Kew.

Brandt, M. (1914). Übersicht über die afrikanischen Arten der Gattung Rinorea Aubl. Bot. Jahrb. Syst. 51: 405-418.).

Cable, S. \& Cheek, M. (1998). The Plants of Mt Cameroon, a Conservation Checklist. Royal Botanic Gardens, Kew.

Chapman, J. \& Chapman, H. (2001). The Forests of Taraba and Adamawa States, Nigeria an Ecological Account and Plant Species Checklist. University of Canterbury: Christchurch, New Zealand. pp. 221.

Cheek, M. (1992). A Botanical Inventory of the Mabeta-Moliwe Forest. Royal Botanic Gardens, Kew.

Cheek, M. (2017). Rinorea simoneae. The IUCN Red List of Threatened Species 2017: e.T110087540A110087542. https://dx.doi.org/10.2305/IUCN.UK.20173.RLTS.T110087540A110087542.en. (Downloaded on 09 May 2021).

Cheek, M. \& Haba, P. M. (2016). Spiny African Allophylus (Sapindaceae): a synopsis. Kew Bulletin 71: 55. https://doi.org/10.1007/S12225-016-9672-3

Cheek, M., Alvarez-Aguirre, M.G., Grall, A., Sonké, B., Howes, M.-J.R., Larridon, I. (2018a). Kupeantha (Coffeeae, Rubiaceae), a new genus from Cameroon and Equatorial Guinea. PLoS ONE 13(6): e0199324. https://doi.org/10.1371/journal.pone.0199324

Cheek M., Etuge M., Williams S. (2019). Afrothismia kupensis sp. nov. (Thismiaceae), Critically Endangered, with observations on its pollination and notes on the endemics of $\mathrm{Mt}$ Kupe, Cameroon. Blumea - Biodiversity, Evolution and Biogeography Of Plants. 64(1): 158164 https://doi:10.3767/blumea.2019.64.02.06

Cheek, M., Gosline, G., Onana, J-M. (2018c). Vepris bali (Rutaceae), a new critically endangered (possibly extinct) cloud forest tree species from Bali Ngemba, Cameroon. Willdenowia 48: 285 - 292. doi: https://doi.org/10.3372/wi.48.48207

Cheek, M., Harvey Y., Onana J-M. (2010). The Plants of Dom, Bamenda Highlands, Cameroon, A Conservation Checklist. Kew, Royal Botanic Gardens.

Cheek, M., Harvey, Y., Onana, J.-M. (2011). The Plants of Mefou Proposed National Park, Yaoundé, Cameroon, A Conservation Checklist. Kew, Royal Botanic Gardens.

Cheek, M., Mackinder, B. Gosline, G., Onana J.-M., Achoundong, G. (2001). The

Cheek, M., Nic Lughadha, E., Kirk, P., Lindon, H., Carretero, J., Looney, B.,Douglas, B., Haelewaters, D., Gaya, E., Llewellyn, T., Ainsworth, M., Gafforov, Y., Hyde, K., Crous, P., Hughes, M., Walker, B.E., Forzza, R.C., Wong, K.M., Niskanen, T. (2020). New scientific 
discoveries: plants and fungi. Plants, People Planet 2:371 - 388 .

https://doi.org/10.1002/ppp3.10148

Cheek, M., Onana, J-M., Pollard, B.J. (2000). The Plants of Mount Oku and the Ijim Ridge, Cameroon, a Conservation Checklist. Kew, Royal Botanic Gardens.

Cheek, M., Pollard, B.J., Darbyshire, I., Onana, J-M., Wild, C. (2004). The Plants of Kupe, Mwanenguba and the Bakossi Mountains, Cameroon: A Conservation Checklist. Kew, Royal Botanic Gardens.

Cheek, M., Tchiengué, B., van der Burgt, X. (2021). Taxonomic revision of the threatened African genus Pseudohydrosme Engl. (Araceae), with P. ebo, a new, critically endangered species from Ebo, Cameroon. PeerJ 9 :e10689 https://doi.org/10.7717/peerj.10689

Cheek, M., Tsukaya, H., Rudall, P.J., Suetsugu, K. (2018b). Taxonomic monograph of Oxygyne (Thismiaceae), rare achlorophyllous mycoheterotrophs with strongly disjunct distribution. PeerJ, 6, e4828. https://doi.org/10.7717/peerj.4828

Cheek, M. \& Williams, S. (1999). A Review of African Saprophytic Flowering Plants. In: Timberlake, Kativu eds. African Plants. Biodiversity, Taxonomy \& Uses. Proceedings of the 15th AETFAT Congress at Harare. Zimbabwe, 39-49.

Darbyshire, I. \& Cheek, M. (2004a). Rinorea fausteana. The IUCN Red List of Threatened Species 2004:

e.T46185A11034817. https://dx.doi.org/10.2305/IUCN.UK.2004.RLTS.T46185A11034817.e n. (Downloaded on 09 May 2021).

Darbyshire, I. \& Cheek, M. 2004b. Rinorea thomasii. The IUCN Red List of Threatened Species 2004:

e.T46186A11034916. https://dx.doi.org/10.2305/IUCN.UK.2004.RLTS.T46186A11034916.e n. (Downloaded on 01 May 2021).

Darbyshire, I., Anderson, S., Asatryan, A., Byfield, A., Cheek, M., Clubbe, C., Ghrabi, Z., Harris, T., Heatubun, C. D., Kalema, J., Magassouba, S., McCarthy, B., Milliken, W., Montmollin, B. de, Nic Lughadha, E., Onana, J. M., Sa1dou, D., Sarbu, A., Shrestha, K. \& Radford, E. A. (2017). Important Plant Areas: revised selection criteria for a global approach to plant conservation. Biodiversity Conservation 26: 1767 - 1800.

https://doi.org/10.1007/s10531-017-1336-6

Harvey, Y., Pollard, B.J., Darbyshire, I., Onana, J-M., Cheek, M. (2004). The Plants of Bali Ngemba Forest Reserve, Cameroon. A Conservation Checklist. Kew, Royal Botanic Gardens.

Harvey, Y.H., Tchiengue, B., Cheek, M. (2010). The plants of the Lebialem Highlands, a conservation checklist. Kew, Royal Botanic Gardens.

Humphreys, A.M., Govaerts, R., Ficinski, S.Z., Lughadha, E.N. and Vorontsova, M.S. (2019) Global dataset shows geography and life form predict modern plant extinction and rediscovery. Nature Ecology \& Evolution 3.7: 1043 - 1047. https://doi.org/10.1038/s41559019-0906-2 
IPNI (continuously updated). The International Plant Names Index. Available from: http://ipni.org/ [accessed Mar. 2018].

IUCN (2012). IUCN red list categories: Version 3.1. Gland, Switzerland and Cambridge, U.K., IUCN Species Survival Commission.

Lovell, R. (2020). Timber ! The threat to Cameroon's Ebo Forest. https://www.kew.org/readand-watch/ebo-forest-cameroon (accessed 5 May 2021).

Maisels, F.M., Cheek, M., Wild, C. (2000). Rare plants on Mt Oku summit, Cameroon. Oryx 34: 136 - 140. https://d oi.org/10.1017/s0030605300031057.

Moxon-Holt, L. \& Cheek, M. (2021). Pseudohydrosme bogneri sp. nov. (Araceae), a spectacular Critically Endangered (Possibly Extinct) species from Gabon, long confused with Anchomanes nigritianus. BioRxiv (pre-print) https://doi.org/10.1101/2021.03.25.437040

Nic Lughadha, E., Bachman, S.P., Leão, T.C., Forest, F., Halley, J.M., Moat, J., Acedo, C., Bacon, K.L., Brewer, R.F., Gâteblé, G. and Gonçalves, S.C. (2020). Extinction risk and threats to plants and fungi. Plants, People, Planet, 2(5), pp.389- 408.

https://d oi.org/10.1098/rstb.2017.0402

Onana, J.-M. (2011). The vascular plants of Cameroon, a taxonomic checklist with IUCN Assessments. Kew, Royal Botanic Gardens.

Onana, J.-M., Cheek, M. (2011). Red data book of the flowering plants of Cameroon, IUCN global assessments. Kew, Royal Botanic Gardens.

Plants of the World Online (continuously updated). Facilitated by the Royal Botanic Gardens, Kew. http://www.plantsoftheworld online.org/?f=accepted_names\&q=Vepris (accessed 1 Nov. 2021)

Rokni, S., Davis, A.P., Cheek, M. \& Sonké, B. (2017). Argocoffeopsis spathulata. The IUCN Red List of Threatened Species 2017:

e.T110079511A110079513. https://dx.doi.org/10.2305/IUCN.UK.20173.RLTS.T110079511A110079513.en. Downloaded on 30 October 2021.

Sosef, M.S.M., Wieringa, J.J., Jongkind, C.C.H., Achoundong, G., Azizet Issembé, Y., Bedigian, D., Van Den Berg, R.G., Breteler, F.J., Cheek, M., Degreef, J. (2006). Checklist of Gabonese Vascular Plants. Scripta Botanica Belgica 35. National Botanic Garden of Belgium.

Tchoutou, M.G.P. (2004). Plant Diversity in a Central African rainforest: implications for biodiversity conservation in Cameroon. Wageningen University, Netherlands.

Thiers, B. (continuously updated). Index Herbariorum: A global directory of public herbaria and associated staff. New York Botanical Garden's Virtual Herbarium. [continuously updated]. Available from: http://sweetgum.nybg.org/ih/ [accessed: March 2021].

Turland, N. J., Wiersema, J. H., Barrie, F. R., Greuter, W., Hawksworth, D. L., Herendeen, P. S., Knapp, S., Kusber, W.-H., Li, D.-Z., Marhold, K., May, T. W., McNeill, J., Monro, A. M., Prado, J., Price, M. J. \& Smith, G. F. (eds.) (2018). International Code of Nomenclature for algae, fungi, and plants (Shenzhen Code) adopted by the Nineteenth International Botanical 
Congress Shenzhen, China, July 2017. Regnum Vegetabile 159. Glashütten: Koeltz Botanical Books. DOI https://doi.org/10.12705/Code.2018

van Velzen, R., \& Wieringa, J. J. (2014). Rinorea calcicola (Violaceae), an endangered new species from south-eastern Gabon. Phytotaxa, 167(3): 267 275. https://doi.org/10.11646/phytotaxa.167.3.5

van Velzen, R., Wahlert, G.A., Sosef, M.S., Onstein, R.E., Bakker, F.T. (2015). Phylogenetics of African Rinorea (Violaceae): Elucidating Infrageneric Relationships using Plastid and Nuclear DNA Sequences. Systematic Botany 40 (1). 174 - 184.

https://d oi.org/10.1600/036364415X686486

Wahlert, G. A. (2010). Phylogeny, biogeography, and a taxonomic revision of Rinorea (Violaceae) from Madagascar and the Comoro Islands. Ph.D. Thesis. Athens: Ohio University.

Wahlert, G. A. \& Ballard, H.E. (2012). A phylogeny of Rinorea (Violaceae) inferred from plastid DNA sequences with an emphasis on the African and Malagasy species. Systematic Botany 37: 964 - 973. https://d oi.org/10.3389/fpls.2020.00520

Wahlert, G.A., Gilland, K.E. and Ballard, H.E. (2020). Taxonomic revision of Rinorea ilicifolia (Violaceae) from Africa and Madagascar. Kew Bulletin, 75(1) : 1 - 15. https://doi.org/10.1007/s12225-020-9866-6 